\author{
David Anthony \\ Pittaway \\ Dr DA Pittaway, Institute \\ for Coastal and Marine \\ Research (CMR), Nelson \\ Mandela University. \\ E-mail: \\ pittaway@gmail.com
}

DOI: http://dx.doi.

org/10.18820/24150479/

aa53i1.6

ISSN:0587-2405

e-ISSN: 2415-0479

Acta Academica .

2021 53(1): 115-128

(C) Creative Commons

With Attribution (CC-BY)

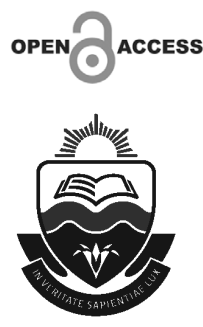

\section{Author interview and book review: Why nothing seems to matter any more by Bert Olivier}

\section{Introduction}

Bert Olivier has written a book in which he argues that nihilism is a pervasive feature of our era. That being said, it should not take readers very long to realise that what appears to be the main focus of the book, namely nihilism, is something of an alibi used by this experienced, skilled, and passionate philosopher to lure them into an illuminating and kaleidoscopic world of lesser-encountered concepts, ideas, themes and issues stemming not only from philosophy and critical theory, but also film, politics, architecture, music, ecology, science, and psychoanalytic theory.

Olivier kindly agreed to answer several questions I had about Why Nothing Seems to Matter Any More (Olivier 2020), and thereafter he joined me to talk about some aspects of the book (thematically linked to the written interview) in a podcast-style interview (Pittaway 2021). ${ }^{1}$ After the written answers to follow, I offer a review of the book, a review that emerged from a combination of my reflections on the contents of Olivier's

The podcast is available here: https://www.perspectiveproject. co.za/2021/05/13/podcast-interview-with-prof-bertolivier-on-his-new-book-why-nothing-seems-to-matterany-more/ 
book, his formal written interview, and the less formal podcast interview.

DP: David Pittaway

BO: Bert Olivier

DP: It looks to me like your new book is only partly about nihilism, but below that surface it is about far more than that. So let's start with level one: how would you summarise your analysis (as you present it in the book) of our nihilistic age?

BO: That's quite difficult, if you want me to offer a summary that relates nihilism - particularly the two Nietzschean types that are responses to the awareness of the abyss of meaninglessness yawning before us - to all the various contemporary manifestations of it scrutinised in the book. But at the risk of oversimplifying, what emerged in the course of writing this text is a culture in the grip of the technological hijacking of society by neoliberal capitalism - a culture suffused by a technocratic spirit (which is hardly a 'spirit') that progressively equates everything that exists with what can be technically mastered. Needless to stress, as Gil Germain has argued, this has the effect of making everything appear to be the 'same', hiding the crucial truth, that humans can only really know themselves, in the Socratic spirit of 'Know thyself', when entering into a relationship with what is 'other', such as nature in all its alterity. That is not really a brief summary, so let me try again - the present is probably the most nihilistic in the entire history of humankind - a nihilism, in the sense of the absence of value(s), which has been progressively brought about by an economic system which ultimately equates all intrinsic value (such as your love for a person) with exchange value. This is not only reductionist, but also plainly false; things do have qualitatively different value, even if this is at present covered up by a nihilistic smog.

DP: Is my hunch correct, that the book is about far more than just nihilism?

BO: It is correct, of course, in so far as nihilism is the outcome of a series of ongoing reactions - as distinguishable from actions, as Nietzsche might say - to socio-economic changes in societies globally in the last 100 years or so. On that distinction, it is precisely those among us who are capable of genuine action, as opposed to reaction, who find meaning in our lives - in other words, in Nietzsche's terms, the active nihilists among us don't have any problem with meaning in our lives; it is the passive nihilists, who merely react to the demands of convention, that face a life of meaninglessness, because their lives are not shot through with values creatively appropriated, but with the pseudo-values generated by the mainstream economic system by technological means. Hence, the book is about this whole, encompassing socio-economic, technocratic system within 
which the world, and nature, are devalued, and merely used as a means to an economic-cratological (power-related) end.

DP: You take an eclectic approach when presenting your subject matter. At times you unpack challenging philosophical concepts; then you tackle ecological issues; then you approach an issue by way of contemporary film or architecture. Why did you choose to take this approach, and what do you hope it will achieve as far as reader responses go?

BO: Interesting question, David, and well observed. It makes me think about what a Belgian reviewer of a previous book of mine - Philosophy and Psychoanalytic Theory (2009) - wrote about it, that it seems to have been written by someone who likes teaching by utilising examples to demonstrate how theory works. I think I may have been influenced in this respect by one of my favourite thinkers (who also features in the present volume, as you will know), Slavoj Žižek, who writes very much in this style. But it is not only a matter of style, with the purpose, partly at least, of 'entertaining' readers in the same way as a lecturer entertains students to retain their attention. It is also, more importantly, a methodological issue in the sense of writing in such a manner that the complex, rhizomatic intertwinement of all things or phenomena is actively demonstrated. People who don't read the poststructuralists - including Lyotard, Derrida, Lacan, Kristeva, Nancy, Foucault, and perhaps above all, Deleuze and Guattari (from whom the philosophical use of the botanical concept 'rhizome' and the related concept of 'assemblage' stem) - simply do not understand that 'everything (under the sun, and including the sun) is interconnected'. It is the principle of encompassing interrelatedness, in other words, in an ontologically multi-level or multi-dimensional sense. To do justice to one's understanding of the unmitigated complexity of the world, one has to think, and write, in a way best suited to this complexity, and I am afraid a traditional, linear kind of writing would not do the trick. This is the principal reason why I write in what might be termed a philosophically picaresque manner, drifting from one philosophical, social, economic, ecological, cinematic or literary milieu to the next, but - and this is an important but - without relinquishing a painstaking drawing of demonstrable connections between and among ostensibly unrelated phenomena, which are argumentatively demonstrated, or associatively shown to be connected, after all (keeping in mind Wittgenstein's distinction between 'showing' and 'saying'). Derrida and other poststructuralists have often been criticised for obscurantism, while in truth they (particularly Derrida) write in a broadly 'rhizomatic' manner that enables them to follow, and uncover, the intricate connections among divergent issues. I deliberately use the term 'picaresque', above, with its derivation from the Spanish 'picaro' in mind - an 'adventurer' of sorts, who associates with what used to be called the lower classes - because I have an inborn contempt 
for people who elevate themselves above other human beings, particularly those labelled the (neoliberal) 'elites' of the world (and/or the so-called celebrities) by Manuel Castells in our era.

DP: In the book, you don't hold back from critiquing neoliberal capitalism, as well as its co-opting of (for example) technology. When reading those analyses, I was struck by the parallel that seems to be emerging as we find out more (seemingly every day) about how monopolistic political and corporate entities have co-opted the Covid-19 pandemic to further their agendas of legitimation, control, and profit. How does the book indirectly address that phenomenon?

BO: As you know, I refer to the so-called 'pandemic' - so-called because, considering the survival rate of in the region of $99 \%$, it is decidedly not a pandemic - in the book's Introduction, which I wrote last, although that was in the early stages of the unfolding of the (so-called 'novel') coronavirus saga, so that I did not have the benefit of hindsight at the time. At this stage, however, there is no doubt in my mind that, as you put it, "monopolistic political and corporate entities have co-opted the Covid-19 pandemic to further their agendas of legitimation, control, and profit'. Like you, I do not rely on mainstream media for reliable information about the 'pandemic', for obvious reasons, chief of which is that all the mainstream media are owned by the monopolistic corporate conglomerates, in all of which the economic elites that meet annually at Davos, arrogating to themselves the right to decide on the fate of the rest of the world, have a stake. So, to answer your question, yes, indirectly the book addresses this issue, particularly where I elaborate on questions raised by Manuel Castells concerning the 'network society' (issues that implicate the economic 'elites'), and especially by Bernard Stiegler, whose untimely recent death was a shock to Continental philosophers, and whom I regard as the most important contemporary thinker. He is foremost among the very few who had the courage to identify the culprit regarding the many crises facing humanity today - including the greatest crisis in its history, the ecological crisis - namely the economic system known as neoliberal capitalism.

DP: In light of gradually emerging information that is showing convincingly that a mono-dimensional pandemic narrative was punted by various private and public entities, how would you respond to someone who claims (in criticism of your argument about nihilism) that the role of the philosopher is to champion scientific progress? Hindsight is surely showing us that what often looks like science is tobacco science, or am I way off the mark here?

BO: Someone like that would reveal their ignorance about the trenchant critique of philosophy dating back to Montaigne and Jean-Jacques Rousseau, and more recently members of the Frankfurt School of Critical Theory, who 
have demonstrated that science is implicated in the 'dialectic of enlightenment', which may have seemed to have rational, social and cultural enlightenment as its principle(s) and goal around the 18th Century, but which gradually revealed itself as the chief source of human unfreedom and oppression through administrative and technological imperatives. I am thinking particularly of Adorno and Horkheimer's Dialectic of Enlightenment and Marcuse's One-Dimensional Man, but other works and thinkers could be added to these, such as Foucault and Lyotard. Today, of course, the appeal to science is abused to the hilt to justify promoting experimental vaccines as the 'products of science', while they have precisely not jumped every scientific hurdle to ensure their safety. Hence the accuracy of your 'tobacco science' allusion; Big Tobacco claimed for years that smoking was safe, and we all know what happened to that claim when scientific evidence eventually exposed the dangers of smoking. Similarly, Pfizer and Moderna - which have produced novel mRNA 'vaccines' - claim that these are the result of scientific research, but they are as yet untested; the global vaccination programme is precisely part of what should have preceded its implementation as clinical trials. Is that justifiable 'science'? I think not. Moreover, when one looks at the billions of dollars' worth of compensation for 'damage' that Pfizer has had to pay in its history, it is not encouraging as far as its scientific status goes!

DP: Late in the book, you quote Horkheimer to convey the point that "[t]he real social function of philosophy lies in its criticism of what is prevalent". Among other things, you have fulfilled this philosophical role in your book. Despite my support for this important aspect of philosophy, I fear that it is like talking about a raging fire rather than doing anything to put out the fire, and right now our planet is burning. How would you respond to my fear?

B0: Hegel famously said that 'the owl of Minerva only spreads its wings at dusk' - a reference to the traditional notion that philosophy is only able to scrutinise and interpret historical events once they have happened. Since then we have learned from Foucault - on whom I spend far too little time in the book that there are different kinds of intellectuals, such as the 'organic intellectual' and the 'critical intellectual'. While understanding why Hegel held the belief alluded to, and certainly eschewing the role of the organic intellectual - who speaks on behalf of an identifiable community or society - I would link Foucault's notion of the critical intellectual - who addresses important issues as they are, with a view of contributing to changing what needs to be changed - with Horkheimer's remark on the social function of philosophy. That said, I have no illusions about my book contributing in any important, let alone direct, way to putting out the fire you refer to. At best, it can - as lan Parker said about psychoanalysis - help to prepare people who read it for the possible social 'revolution', by bringing about a 'internal revolution' in their psyche. Psychoanalysis is exemplary in this respect; 
if my book can achieve something similar I would be gratified. Let me add to this answer by simply saying that - to repeat an ancient idea about philosophy - I hope the book brings about a 'wholesome unrest' in their souls'. Without such 'wholesome unrest' (which amounts to what Kristeva called a personal 'revolt', that is, a 'return to oneself") we certainly would not see the emergence of the kind of humane and human world that humans would recognise as their home.

DP: Nature features as a prominent topic in the book - I would go so far as to say that you venerate it. Would it be correct to read into your discussion of nature and its multifaceted importance a remedy for nihilism?

BO: Certainly it would. My partner and I have just returned from a hiking and mountain-climbing weekend in Hogsback - one of the most beautiful places in South Africa as far as natural beauty goes. It impressed upon me anew the crucial role of entering into an intimate relation with nature when it comes to (re-) affirming the indispensable place of nature in humans' lives. This includes the repeated experience that nature is similar and other to us at the same time; one recognises the presence of other living being's, like trees, honey bees, lizards and antelope, which share life with us humans, but one also encounters the otherness of nature - the fact that it has not been technologically constructed for our pragmatic benefit, that it is obdurate, that one encounters resistance when you try to impose your will on nature, particularly when you climb three mountains consecutively, and you find that you have to obey the demands and limits of your body. This is, paradoxically, what imparts value to one's life - not owning the latest smartphone or German sedan. As my friend and fellow philosopher Gil Germain has remarked in several of his books, technology enables humans to construct a world that is increasingly homogeneous - the same everywhere and this is precisely what promotes passive nihilism, because one is robbed of experiencing the world as independent of us. This is why affirming nature is indispensable for a meaningful life - with the caveat that we do not have access to unmediated, 'objective' nature; nature is always, ineluctably, approached through cultural lenses, including those of science.

DP: You refer to "global elites" frequently in the book, referencing (for example) Castell's phrases "social elites" and the "managerial class". Is there perhaps something problematic in this potentially binarising framing, an us-them dichotomy that does not account for the impossibility of where to draw the line between the "elites" and "the rest of us", the latter being a phrase you use three times? Could you provide some clarity on who the elites are?

BO: I think Castells has already done that; they are precisely the managerial class that you refer to, and I believe one might add the political 'elites' who are in their pockets, as it were. It is not difficult to identify them at all - have a 
look at those who attend the annual Davos celebratory and self-congratulatory assembly. But I think it would be a mistake to regard this as a fixed binary chasm; in the book you once gave me, The Corporation, Joel Bakan relates the case of a member of these elites, who became increasingly conscientised in the course of having to report the ecological liabilities of the company he 'managed', and eventually left the corporate world altogether to focus on remedial ecological work. So the line that separates the elites from the rest of us is not absolute.

DP: Finally, what do you hope readers will come away with from reading Why Nothing Seems to Matter Any More?

BO: An awareness that they - we all - have to reaffirm our relation to and with Mother Nature (who spawned all creatures; nothing is more creative than nature, as we learned from Darwin) - in various ways at an intellectual, but more importantly, practical-ethical and pragmatic restorative level, such as the permaculture you practice. This is imperative to rediscover meaning in one's life, and possibly to avert the looming ecological crisis, as I am sure you'll agree.

\section{DP: Commentary and Review}

Some of what Bert Olivier says in the written interview (above), in the audio interview (Pittaway 2021), and in his new book (Olivier 2020), may not sit well with some readers and listeners. These people may tend, like Steven Pinker (2011), to see the glass of civilisation as at least half full, which is a view that is, of course, justifiable. They may believe and argue that despite some of the terrible downsides that have accompanied the historical march of progress and civilisation, more people than ever have access to, for example, flushing toilets, electricity, medicine, education, the internet, an array of consumer goods that enhance their living standards, reasonable political representation, a good shot at justice if they need to pursue it, and so on. At first glance, these thing's seem self-evidently good and desirable, so it is understandable that many people would like to keep what looks like the march of progress going and simply make things better as humanity heads onwards and upwards.

But Olivier is an insatiable researcher, and he has interwoven a plethora of information to educate and equip readers to see well beyond the entrancehall's trophy-case of what may appear to be civilisation's achievements. To illustrate how he does this, consider his incorporation of the idea of technology as pharmakon - "simultaneously a poison and a cure" (Olivier 2020: 64). In one of the more conceptually challenging parts of the book, Olivier writes:

Stiegler's use of the concept of a pharmakon - simultaneously a poison and a cure - is indebted to Derrida's, and here refers to the potential of "hypomnesic" 
technology, that is technology that takes archiving or memory to a different, posthuman, or perhaps in-human level. Such technology is embodied in the technics of computers, smartphones, the internet and robotics, and as he pointedly states, it may lead to robbing consumers of their internalised memory and knowledge or savoir-faire ["know-how"] as well as (given the harnessing of consumers' desires by capitalist agencies) their savoir-vivre [knowledge of how to live your life], or it may possibly lead to an 'intensification' of critical reflection and action. Needless to stress, it is the latter possibility that Stiegler tirelessly promotes, because it is the only thing that may rescue people at large from being deprived of their ability to resist their ongoing reduction to mere 'consumers' as the pawns of capital (Olivier 2020: 64).

This extract makes it clear that it would be a misunderstanding to see Olivier as a technophobe, especially in light of his open acknowledgement that he uses technology all the time - but crucially, he tries to prevent technology from using him. How would it use him? In exactly the counter-intuitive way that he has explained in the extract above - by dramatically reducing many people's cognitive ability to recall, some of their kinaesthetic capacities to do things, and aspects of their volitional and self-actualisation faculties.

Note that in the previous extract, Olivier's explanation takes into account ideas from two important thinkers, allusions to several prominent themes in philosophy, objects of technology that billions of people use on a daily basis, and a subtle warning to readers about a possible consequence of aspects of the phenomenon under scrutiny. This is a good representation of Olivier's style, which he describes as picaresque in the sense that it is adventurous, but it is also rhizomatic in the sense that it displays an inherent and perhaps stubborn interconnection between things. Olivier is doing far more than merely presenting an argument about nihilism; in presenting his argument, he bursts open numerous cans of worms in a post-structuralist manner so that readers can glimpse the complexity of what lies beneath structuralist snapshots of the world, snapshots that those people who one-sidedly champion progress often tend to battle to incorporate into their world-views.

Structuralist snapshots are obviously useful - indeed, they are crucial as frameworks from which to work, to think, to decide, to act, to communicate, and even to exist. But all thing's - organisms, ideas, societies, technologies, economies - arise out of the dynamism and flux of complex systems. While lip service is often given to complexity (most notably in academic circles), neoliberal capitalist consumerism has funnelled human endeavours in a very narrow direction. Olivier addresses different aspects of this funnelling process throughout the book, for example, by referring to Manuel Castells' important work 
on the space of flows (which is crucial for understanding some of the impacts of internet-based communications and technologies), as well as insights from Gil Germain. Elaborating on the latter, Olivier (2020: 205-6) writes:

Germain delivers a tour de force $[\ldots]$ by contrasting a life cognisant of the need for experiencing the 'otherness' and 'open-endedness' of the world, on the one hand, with one that is hell-bent on eradicating [...] otherness and openendedness in favour of 'sameness' (in the sense of being of human construction) and optimal control or predictability, on the other.

Olivier then refers to a short story called "Jon" (by George Saunders, a story that Germain also unpacks) to alert readers to a potential (nihilistic) consequence of giving in fully to the seemingly innocuous consumerist delights that are everywhere on offer. The short story, summarised in some detail by Olivier, presents a scenario where "technology is employed to gratify all needs" in a "capitalist consumer paradise" (Olivier 2020: 208). He (Ibid) uses "Jon" to illustrate how the gratification of all needs can only occur "in appearance, because a fully satisfied consumer is anathema to capitalism; at best the semblance of satisfaction should be created." Olivier works throughout the book to explore and explain similar phenomena, taking care to alert readers to possible slippages into nihilism that might ensue: "the axiological nature of human lives [is that] we are creatures who value things (more or less all the time, mostly unconsciously), and should remind ourselves of this frequently, lest we become anaesthetised by the fog of nihilism emitted by capital and its ally, technology, at those times when we relax our vigilance" (Olivier 2020: 211-212).

Olivier gives considerable attention to the relationship between the fog of nihilism and what may loosely be referred to as the ecological crisis. In a chapter called "Ecology and Nihilism", he first recruits none other than Slavoj Žižek to raise the issues of "ecological breakdown" (Olivier 2020: 139), the burying of heads in the sand as a response to potentially apocalyptic changes in climate and ecology, and the ethically reprehensible actions of "Big businesses and state powers" that are, according to Žižek (quoted in Olivier 2020: 140),

already looking for new economic opportunities, which concern not only (or even primarily) 'green industry,' but much more simply the potential for further exploitation of nature opened up by climatic changes ... according to current estimates, up to one quarter of the world's untapped oil and gas sources may lie under the Arctic Ocean.

In a stylistic move that might surprise the more academic of readers, but delight others, Olivier turns later in the same chapter to the story of Watership 
Down to illustrate some hard-hitting points pertaining to nihilism and ecology. After his summary of the story, he points out that

at this moment we are like rabbits caught in the glare of a car's headlights, unable to move, just waiting for the inevitable, pretending that nothing has changed. We are like the sophisticated, nihilistic rabbits that enjoy their 'economy of luxury', conveniently ignoring the price they will all, sooner or later, pay for this abundance of 'flayrah', or king's food. In other words, they have been alienated from their true rabbit nature, which is to recognise a threat to life and act accordingly by taking evasive action. (Olivier 2020: 137)

Our flayrah is constituted in part by the luxuries, comforts, technologies, and distractions of a political economy built on the ideological foundations of endless growth and consumption, as well as many of the objects in the entrance-hall's trophy-case of assumed benefits accompanying the expansion of neoliberal capitalism's "progress" and (shallow) democracy. Some readers might be annoyed by another reference to neoliberal capitalism as a culprit here, as well is in Olivier's book, seeing as he makes frequent use of the term. It may seem banal to keep going on about neoliberal capitalism and its causal role in the ecological crisis, but considering that, first, the doomsday clock is now at 90 seconds to midnight (Weisberger 2020), and second, that thanks to Covid-19 everybody now officially loves the precautionary principle (Pittaway 2020), it is of paramount importance to grasp the nature of the ecocidal beast: monopolistic corporate entities paved the way for neoliberal capitalism to infiltrate and conquer almost every aspect of the present social, political, economic, and ecological dispensation, and the success of the strategic takeover (facilitated, in part, as Olivier shows, by technology) is what has allowed for those entities to accelerate their war against nature and non-consumerist values for the sake of astronomical financial profits. One of the consequences of this and other lesser-scrutinised phenomena, argues Olivier, is that nothing seems to matter anymore, and he provides readers with a philosophical toolbox packed with an assortment of conceptual tools to understand what is going on.

As Olivier has emphasised, nature is a prime example of something (or rather, a complex of things) that can be viewed as having inherent value. It is inherently valuable in that it needs not be incorporated into the world of human exchange value (which is a form of instrumental value) for it to be a meaningful part of human life. However, Olivier, via Germain, has gone further and explained that nature has value partly because it facilitates the experience of 'otherness' in its (once) endless multiplicity for human beings. In a passage that illustrates some aspects of this 'otherness', as well as his agility in incorporating objects and 
ideas from just about everywhere into his writing and thinking, Olivier (2020: 223-4) writes:

Think of the light-and-dark, day-and-night rhythm of life, so beautifully captured in the Moody Blues' album, Days of Future Passed (who can ever forget 'Nights in white satin'?) - when the sun rises we engage in different actions, compared to when it sets, and so on. This is the rhythm of nature, even if we never consciously admit it, and sometimes need to be prompted by cultural artefacts like the Moody Blues' music to take notice. And once we do take notice of the inescapable presence of nature in our lives, we may just begin to (re-)discover how it imbues our lives with values - the value (and valence) of different shades and hues of light and darkness, for example - compare the different significance of sunrise as opposed to sunset, for instance, so poignantly embodied in the song from the musical, Fiddler on the Roof, 'Sunrise, Sunset', which celebrates, and simultaneously laments, the natural temporality, light and darkness-related rhythm of life.

If anyone doubts that neoliberal capitalism, under the (mis)guidance of profitand power-hungry global elites and the managerial classes, has had (deliberately or accidentally) the impact of destroying what may be called natural value, then consider the case of the indigenous people of Ecuador (as represented in courts by Steven Donziger and other lawyers) against the oil company, Texaco, which was bought by Chevron, thus making (in theory) the latter corporation legally responsible for the actions of the former. This is not something that Olivier writes about; it is referred to here because it drives home what is at stake if humanity fails to tame the ecocidal beast of neoliberal capitalism, regardless of whether one believes that such a system is a "natural" extension of various human traits. Olivier is a passionate thinker and writer who, via Why Nothing Seems to Matter Any More (2020) in particular, and his writing in general (in the form of academic journal articles and Thoughtleader.co.za articles), pushes readers to confront the beast in an insightful authorial manner, at a time in history when radical changes towards ecocentric systems are urgently required.

The details of the case of the Ecuadorian People vs. Chevron/Texaco are here extracted from a long interview with Donziger at Chris Ryan's podcast (which comes highly recommended), named "Tangentially Speaking", episode 470, though details of the decades-long saga are widely available online (see, for example, Savage 2021). In short, Texaco destroyed a large and uniquely biodiverse region of Amazonian rainforest during the company's mining for oil there, deliberately dumping toxic waste in order to cut costs, causing diseases such as 
cancer in the local people, and a host of other problems for the people and animals living there. Thanks to Donziger and many other lawyers, the case culminated after eight years with Ecuadorian judges ruling in favour of the Ecuadorian people, and with Chevron ordered to pay billions of dollars in compensation to the victims of Texaco's crimes.

But Chevron did not pay and make amends. Instead, it cleared out of the country and appealed against the Ecuadorian ruling in a North American court, with a team of Chevron lawyers training a false witness to lie and defame Donziger (Hershew 2017) in front of the judge appointed to the case, Judge Kaplin, a former tobacco lawyer. A private prosecutor - Rita Glaven - who works for a Chevronlinked law firm, was appointed to take further the charge against Donziger. By May 2021, Donziger had spent over 600 days under house-arrest for stepping in to lead the charge against a corporation that is unambiguously guilty of crimes against humanity and the planet. This is not speculation - the original Ecuadorian judges made their decision at the end of an eight-year period, and after reviewing "voluminous scientific evidence, undisputed scientific evidence, ... including 64,000 chemical sampling results that showed that massive pollution had been left behind in Ecuador" (Donziger, in Ryan 28: 23). Donziger points out that over a period of 25 years,

Chevron has invested literally billions of dollars, used at least 60 law firms and 2000 lawyers, to try to make the case more complicated than it is, and to confuse people about the fundamental fact, which is that they went into Ecuador where five indigenous groups lived and played God and made a decision that rather than do it correctly they were just going to dump the waste into the waterways that the indigenous peoples relied on for their drinking water, their bathing, and their fishing, and they produced a cancer epidemic that literally has killed thousands of people over the last 50 years, and they haven't paid one dollar in compensation.

Donziger, explaining why Justice has not been served, continues in a manner that reveals some of what lies beyond what I have dubbed the trophy-case in the entrance-hall of civilisation. His observations also knock the wind out of the sails of the belief in Justice - sure, one can believe that Justice matters, but it is hard to keep the fog of nihilism at bay after the following:

There's been a multi-decade effort to remake the federal judiciary so it's pro corporate and more right wing, and that's done through various organisations like the federalist society [funded in part by Chevron], the Judicial Crisis Network... [and] there's a whole infrastructure... in America to control the judiciary so that 
corporate interests are served over the interests of the people... So a lot of times you go to Federal court and you're a corporation it's just stacked in your favour from the get-g'o. You can get almost any judge on some courts and they're going to be sympathetic to you. In this particular case, Judge Kaplin definitely comes out of that world - he represented Philip Morris [and] Brown and Williamson [both tobacco companies] when he was at the big corporate firm Paul Weiss for 24 years before he was named to the bench... He's one of the most pro-corporate judges imaginable."

For context on Donziger's observations, see Lipton and Peters (2017), and for another overview of the case and saga, see Lerner (2020).

The Chevron vs. Donziger situation is not an accident or aberration within an otherwise squeaky-clean neoliberal capitalist political economy. This is not an example of a fossil-fuel bad egg that has sidestepped due process. This is an example of what, in part, underpins the neoliberal political economy. Vested economic interests are not an impediment to the correct and proper functioning of the global political economy that has been established since the 1950s - on the contrary, vested economic interests have played crucial roles in the processes through which our present consumer dispensation has been established, and in the processes that have given rise to the technologies that influence every aspect of human life. In this dispensation, one can try to ascribe inherent value to, for example, nature, and one can try to access what is left of it in the manner that Olivier writes and speaks about. However, as the Texaco/Chevron example demonstrates, nature has been and continues to be decimated in the pursuit of profit and human expansion, with politics and the legal system largely incapable of speaking anything but the language of "economism", which is a term Olivier (2020: 61) borrows insightfully from Bernard Stiegler.

In the Donziger interview, podcast host Chris Ryan (11: 23) ends his introduction to the episode with the following remark: "I know people work for these companies, but I can't believe that these people could do what they're doing understanding what it is. I think they don't get it - they don't understand, because there is a reality field that is created in which it is impossible to see what you're doing." Bert Olivier's new book addresses various aspects of this reality field, a book that makes it possible "to see what you're doing", or, rather, to see what has been happening for several decades as "designer nihilism" (Olivier 2020: 25) has distracted and conditioned most people via mainly technological means while members of the corporate and political elite laugh all the way to the bank. Olivier enables this "seeing" in his own unique philosophical and pedagogical style, and every reader will be left thinking differently and more clearly about the dispensation in which s/he lives after reading the book. 


\section{Acknowledgements}

The author acknowledges the financial support received (while researching and writing this review) from the Institute for Coastal and Marine Research (CMR) at the Nelson Mandela University (NMU). All views and opinions expressed in this article belong to the author, and do not necessarily reflect any official position or policy of the CMR or NMU.

\section{Bibliography}

HeRSHAw E. 2015. Chevron's star witness admits to lying in the Amazon pollution Case. Available at: Vice. 26 October. https://www.vice.com/en/article/ neye7z/chevrons-star-witness-admits-to-lying-in-the-amazon-pollutioncase [accessed on 3 May 2021].

LERNER S. 2020. How the environmental lawyer who won a massive judgment against Chevron lost everything. The Intercept. 29 January. Available at: https://theintercept.com/2020/01/29/chevron-ecuador-lawsuit-stevendonziger/ [accessed on 3 May 2021].

LIPTON E AND PETERS JW. 2017. In Gorsuch, conservative activist sees test case for reshaping the judiciary. The New York Times. 18 March. https://www.nytimes. com/2017/03/18/us/politics/neil-gorsuch-supreme-court-conservatives. html. Accessed 3 May 2021.

Olivier B. 2009. Philosophy and psychoanalytic theory. Bern: Peter Lang.

OLIVIER B. 2020. Why nothing seems to matter any more: a philosophical study of our nihilistic age. Baltimore, MD: Montagu House.

PINKER S. 2011. The better angels of our nature: a history of violence and humanity. London: Penguin Books.

PItTAWAY D. 2020. To save lives: the ethical precedent set by South Africa's leadership during lockdown. Phronimon 21: 1-19. DOl: 10.25159/2413-3086/8424

PitTAWAY D. 2021. Bert Olivier on his new book, Why nothing seems to matter any more. Perspective project audio 021. Available at: https://www. perspectiveproject.co.za/2021/05/13/podcast-interview-with-prof-bertolivier-on-his-new-book-why-nothing-seems-to-matter-any-more/ [accessed on 3 May 2021].

Ryan C. 2021. 470 - Steven Donziger (Human Rights Lawyer). Available at: https:// chrisryanphd.com/470-steven-donziger-human-rights-lawyer/ [accessed on 3 May 2021].

SAVAGE L. 2021. The Kafkaesque nightmare of attorney Steven Donziger, a literal prisoner of the Chevron Corporation. Jacobin. 15 April. Available at: https:// www.jacobinmag.com/2021/04/attorney-steven-donziger-chevronecuador-prosecution-corruption-trial. [accessed on 3 May 2021].

Weisberger W. 2020. Doomsday Clock is now 100 seconds from midnight. Livescience. 23 January. Available at: https://www.livescience.com/ doomsday-clock-update-2020.html. [accessed on 3 May 2021]. 